Research Article

\title{
Evaluating the challenges in online learning during the COVID-19 pandemic in a middle secondary school
}

\author{
Ngawang Chogyel, Norbu Wangdi and Yeshi Dema \\ Yangchen Gatshel Middle Secondary School, Bhutan
}

\begin{abstract}
With the implementation of lockdown, social distancing measures and stay home initiatives to contain the spread of COVID-19 pandemic, there was a sudden change of pedagogy in education to continue the teaching learning process. This has challenged the education system around the globe. This study was aimed to investigate the challenges faced by the students in conducting online classes during the Corona virus (COVID-19) pandemic in a Middle Secondary School in Thimphu District, Bhutan. Adopting mixed method design, the study employed the structured questionnaire to collect quantitative data and semi-structured interview to collect qualitative data. The respondents for the study comprised of 92 students from classes nine and ten selected based on the purposive random sampling technique adopted. Quantitative data collected were analyzed based on descriptive statistics in the form of percentages using SPSS software, whereas the qualitative data were analyzed based on content analysis technique. The study found that the lack of digital facilities (smart phone, laptop and television), internet facilities and personal related factors impacted the online learning negatively during the corona virus (COVID-19) pandemic. Based on the findings of this study, it offered useful suggestions to teachers, policy makers and the Ministry of Education for the smooth and quality online teaching and learning during emergencies like COVID-19 pandemic.
\end{abstract}

Keywords: Online learning, COVID-19, challenges

\section{Introduction}

Although the online learning has existed for more than a decade, the educational intuitions around the globe have shifted to online classes from the face-to-face classroom interaction more vigorously starting from the time when COVID-19 has affected all levels of global education systems. As a result, the online teaching has gained importance in the present time due to the COVID-19 pandemic because of social distancing measures and stay at home initiatives by governments to contain the spread of pandemic (Drucker \& Fleischhauer, 2021; Kara \& Gök, 2020). Bhutan was no exception to this shift as most governments around the world decided to temporarily close educational institutions in an attempt to contain the spread of the COVID-19 pandemic. The schools in Bhutan began this unplanned shift from traditional learning to online classes overnight. Online education was the only platform to keep the continuity of the education system during the pandemic in spite of some difficulties. The transformation of the national education system in Bhutan from traditional classroom to online as a result of the pandemic is an opportunity for existing unavoidable problems. The pandemic has offered an opportunity to develop online learning for schools in Bhutan which might otherwise have taken longer time. The disruption in learning during the time of the Covid-19 pandemic turned into an opportunity to navigate teaching and learning during the pandemic and beyond (Hammond \& Hyler, 2020).

Address of Corresponding Author

Ngawang Chogyel, Yangchen Gatshel Middle Secondary School, 11001, Thimphu, Bhutan.

$\triangle$ ngawang405@gmail.com

0000-0001-7883-1486

How to cite: Chogyel, N., Wangdi, N., \& Dema, Y. (2021). Evaluating the challenges in online learning during the COVID19 pandemic in a middle secondary school. International Journal of Didactical Studies, 2(2), 101459. https://doi.org/10.33902/IJODS.2021269731 
Educational systems of all countries across the globe turned to online methods of teaching as a solution to the crisis of the COVID-19 pandemic within a short period of time (Rasmitadila, et al., 2020).

As a quick response to the closure of schools across the nation during the COVID-19 pandemic, the volunteer teachers of Bhutan (VToB) in consultation with the ministry of education came up with the initiative of tele-education. The lessons were recorded and broadcasted through the national television in a very short period and were made accessible on YouTube, radio, and TV for children. Therefore, children in schools in Bhutan availed various mediums from television to smart phones, Google classroom and self-instructional materials (SIM) from home to ensure continuity of education during the pandemic. However, the quality and challenges of online classes have remained as a highly debated topic amongst educationists and policy makers in Bhutan. In Bhutan, the students' assessment for online learning, attention for the students with special needs, and non-participative nature of the students were found to be challenging for the educators and the education system (Pokhrel \& Chhetri, 2021).

Students failed to show up for the online classes. Most of the students were not actively participating in the online class conducted through Google classroom most of the time. Teachers at some schools across the country also reported that only a few students are participating regularly in online learning and most of them missed their online classes. The lack of personal smart phones and bad network connections are some of the problems faced by the students during the online classes (Wangmo, et al., 2020). The majority of the students in the remote parts of the country lack internet access. Moreover, some of the students do not have a smart phone or television set and parents are unable to afford it (Rinzin, 2020). This has resulted in students' difficulties in attending the online classes. Hence, we were not prepared for this shift in terms of technology. Many students had to purchase smart phone so as to learn online. Moreover, the children did not have enough digital knowledge for the online classes. A research review done by Sun and Chen (2016) found that online education is powered by internet connectivity, advanced technology, and a massive market. Online education is not effective in African universities because of the inadequate resources like computers, insufficient facilities and poor network (Paschal \& Mkulu, 2020). The prioritized challenges for the students with the online education are network and facility-related challenges, student-teacher interaction-related challenges and personal and socio-psychological challenges (Islam et al., 2020). Lack of proper interaction with instructors and absence of classroom socialization are other major challenges associated with online learning (Adnan \& Anwar, 2020).

Therefore, it is of utmost importance to evaluate the challenges faced by the students so as to analyze the challenges for the smooth and quality online teaching and learning during such pandemic in the future as well. It is on the basis of this that this study was undertaken to investigate the challenges faced by students with online classes during such a pandemic in one of the middle secondary schools in Thimphu District, Bhutan.

This study focuses on evaluating the challenges faced by students in online learning during the Coronavirus Pandemic. The previous studies have shown that the most common challenges related to online learning are due to challenges related to personal factors, lack of internet facilities and digital equipment. Therefore, this study aims to investigate these challenges faced by students in online learning in a middle secondary school in the Thimphu District. The specific questions that guided this study were;

1. What are the challenges that students face in online learning during COVID-19 Pandemic?

2. How do these challenges affect the students' online learning?

\subsection{Literature Review}

Literatures pointed out numerous challenges in Online Classes during the Corona virus (COVID19) for students. The challenges considered in this study are challenges related to personal challenges, internet facilities and digital equipment as discussed below.

With the corona virus pandemic around the globe, there was a sudden change of pedagogy in education. The schools and the universities around the world were unprepared for the sudden switch to online interactions. The sudden transition to online pedagogy as a result of COVID-19 in developing countries has exposed some challenges as well as benefits. Many students who were accustomed to the traditional face-to-face method of teaching before the pandemic found the online method burdensome (Oyedotun, 2020). The burdensome was related to stress experienced as a result of adjusting to online education due to financial constraints, and uncertainty related to their academic performance, graduation, and future career prospects (Sundarasen et al., 2020). A study conducted by Shetty et al., (2020) identified that the lack of face-to-face interactions, lack of 
socialization and distraction by social media are the challenges faced by the students during the online class.

Schools in Bhutan adopted Google Classroom as online teaching and learning tools among many other tools for online teaching and learning from classes VII to XII. Learning through mobile technology through the Google classroom platform is effective provided the students have access to smart phone, laptop and the internet (Sofi \& Laafou, 2020). The lack of internet connectivity, internet data and digital equipment are the challenges faced by students while using Google Classroom (Kado et al., 2020). The most common challenges with online learning were technical insufficiency, including poor internet connectivity and deficits in educators' basic computer skills (Khalil et al., 2020). Online learning is not effective and not very exciting for students as the internet connections do not support the online learning (Wijaya et al., 2020). The students' hardship in learning from home during the pandemic is caused due to the lack of funds to buy internet data, unstable internet network, having the responsibility to help parents, no internet access, slow devices response to run e-learning applications, and difficulty understanding the material (Christiawan et al., 2020). The high data consumption and poor internet connectivity is the biggest challenge faced by the children with the online class. Moreover, the high data consumption makes the online class expensive (Drukpa, 2020). Poor connectivity might prove to be the major cause of other disadvantages of online. Therefore, the internet facility is a very important factor for the learners to interact with the instructors and the learning materials for online classes.

The study by Thanji and Vasantha (2018) showed that the lack of interaction between the learner and instructor was a major limitation experienced by the learner with the online education. The student's active learning process is facilitated by the interactive online learning tools improving the students' test scores significantly (Ha \& Im, 2020). Thus, interactivity plays a very important role in online learning and achieves very good learning outcomes (Preradović et al., 2020). However, despite the challenges, online learning is a blessing towards academic excellence as online learning leads to better student participation during a calamity like the COVID-19 pandemic (Kamal et al., 2020).

The abovementioned discussions provided different perspectives and views which prompted the researchers to conduct this study to find out and justify some of the previous literature's findings and results.

\section{Method}

\subsection{Research Design}

In this study, the convergent parallel mixed method design was adopted. The researcher collected both forms of qualitative and quantitative data at the same time involving the convergent parallel mixed method. According to Creswell (2014), the convergent parallel mixed method requires the researcher to collect both forms of qualitative and quantitative data roughly at the same time. Both qualitative and quantitative approaches were used in this study as mixed method approach provides the best opportunity for addressing research questions (Malina et al., 2011). The both forms of qualitative and quantitative data were collected roughly at the same time.

\subsection{Population and Sampling}

According to Lodico et al., (2006) the population is a wider group of people that interests a researcher. Samples are taken for measurement from a group of an individual, object or items (Kombo \& Tromp, 2006). The population of this study is composed of students between the age group of 13-24 of a Middle Secondary School under the Thimphu district. Purposive random sampling technique was used to select the sample of the respondent. Use of purposive random sampling technique ensures information from every individual in the community is potentially valuable (Tongco, 2007). A sample of 92 student respondents was selected based on the purposive random sampling technique.

\subsection{Data Collection Methods and Instruments}

The instrument for the survey and interview was prepared by the researcher based on the related literature. In order to realize the reliability of instruments, a pilot study was conducted. The instrument yielded a cronbach's alpha reliability of 0.82 upon administering it to 40 students who were not part of the sample. This was considered reliable enough to be used for the study.

The researcher used survey questionnaire and interview as the instruments to capture information for the purpose of this study as discussed below. 


\subsubsection{Questionnaire}

The researchers designed a self-administered structured questionnaire and distributed it online among the students of a middle secondary school of the Thimphu district during the second lockdown. As students were not physically available on the campus, and since social distancing was necessary during the pandemic, these options were ruled out with the alternative of a survey questionnaire. The survey questionnaire was used to explore the students' challenges related to internet facilities, digital equipment, and students' personal challenges for online classes. The questionnaire was based on the 4-point Likert-type scale of strongly agree, agree, disagree and strongly disagree. Because the developed questionnaire is a multiple-choice questionnaire with categorical questions only the content validity was provided instead of carrying out a factor analysis, as recommended in the literature. Expert opinion has been obtained for the content validity.

\subsubsection{Interview}

For this study, the semi-structured interview was used as it allows discussion with the interviewee with the more open-ended questions covering various issues concerning the study. The interview with the students was conducted after the lift of the second lockdown in the last week of January 2021 as a face-to-face interview can help connect the researcher with the participants in a better way. The interview was conducted with 20 students.

\subsection{Data Analysis Procedure}

The quantitative data collected through the survey questionnaire were analyzed using SPSS software in the form of tables and percentages to answer the research questions. The percentage was determined by pooling together strongly agreed and agreed which were regarded as agreed while strongly disagreed and disagreed were pooled together and were regarded as disagreed. The data obtained from the interview was transcribed, coded and were categorized under specific themes and analyzed using content analysis technique. The quantitative data and qualitative data obtained were converged to develop a more in-depth understanding of a research problem.

\subsection{Ethical Considerations}

Prior to carrying out the study, the researcher needs to obtain the clearance letter from an individual authority to gain access to the site and to the study participants. Therefore, in this study, the research clearance letter for the purpose of data collection was obtained from both parents and the Principal. The clearance letter introduced the researcher to the principal and parents of the schools who in turn introduced the researcher to the student participants.

\section{Results}

Students experienced different forms of challenges in online learning during the pandemic. These various challenges experienced by students during online learning are shown in Table 1, 2 and 3 . The data obtained is expressed in terms of percentage against agreed and disagreed, and presented in the tabular form for easy interpretation.

Table 1

Challenges in Online Learning Due to Personal Aspects ( $\mathrm{N}=92)$

\begin{tabular}{lcc}
\hline Statement & Agree & Disagree \\
\hline 1. I feel comfortable to use mobile phone/laptops/tablet for online learning. & $57 \%$ & $43 \%$ \\
2. Online learning is more interesting than classroom learning. & $63.3 \%$ & $36.7 \%$ \\
3. There is no difference between online learning and actual classroom & $22.8 \%$ & $77.2 \%$ \\
learning. & 53.2 & $46.8 \%$ \\
4. Face to face learning is more important than online learning. & \\
\hline
\end{tabular}

The result in Table 1 shows that students do not learn much from the online classes than from the traditional face-to-face classes. This is based on $77.2 \%$ of the total respondents affirming this fact. The challenges in learning online is associated with their own personal difficulties due to the lack of understanding the materials provided by the teachers online $(43 \%)$, lack of enough time to work on the online assignments $(36.7 \%)$ and lack of sufficient knowledge for internet access for online $(46.8 \%)$. Moreover, an average of $50.9 \%$ of the total respondents indicated the learning 
difficulties due to personal factors while an average of $49.1 \%$ indicated no difficulties associated with the personal factors. This difficulty associated accounts for half of the sample respondents.

The reasons cited by the respondents during the interview for not being able to learn effectively from the online classes were the difficulties in understanding the learning materials provided by the teachers. Student- 8 opined that, "It was difficult to understand the learning materials sent by the teachers. Even if the teacher sends the video lesson, we cannot download it as we did not have enough data." Similarly, the above views are further confirmed by Student-13 that "In online we cannot understand the learning materials provided by teachers, and we cannot discuss with our friends like face-to-face teaching".

Most of the students were also of the opinion that online classes overburdened them with too many assignments. This is supported as the students expressed their views as "I did not get enough time to work on the assignments provided by the teachers. I also had to look after my younger brother and sister when my parents were away from home for work" (Student-15). Similarly, Student-18 asserted that "I did not get much time to work on online assignments. There was also a family matter to look at while attending online classes from home".

Most of the participants were not satisfied with online learning because they were not able to learn better from online class compared to face-to-face learning. Student-10 asserted that "Faceto-face teaching is much better than the online class. We can't understand more in an online class. Moreover, we cannot clear our doubts in the online class." Similarly, Student-11 pointed out that:

Face-to-face teaching is better than the online classes. In face-to-face teaching we can ask doubts. But in online class even if we ask questions, the teacher delays the response to our question. The teacher responds to our queries in the Google classroom after a few days only.

It was indicated through analysis that the challenges students faced in online learning during the pandemic include difficulty in understanding the online learning materials provided by the teachers. It was also difficult for them to complete their assignment in the stipulated time as teachers assigned more assignments and because of their involvement in household chores. Thus, students prefer face-to-face teaching and learning instead of online. For this reason, teachers must be able to look for creative ways of teaching online and consider extending the assignment completion time.

Table 2

Challenges in Online Learning Due to Lack of Internet Facilities (N=92)

\begin{tabular}{lcc}
\hline Statement & Agree & Disagree \\
\hline 1. Have funds to buy internet data. & $33.5 \%$ & $66.5 \%$ \\
2. Have sufficient internet data. & $27.8 \%$ & $72.2 \%$ \\
3. Access to stable internet network & $29.5 \%$ & $70.5 \%$ \\
\hline
\end{tabular}

Table 2 shows the percentages of response to the challenges based on the availability of internet facilities. A close look at the percentage on table 1 reveals that the majority of the students have difficulties with the internet facilities. This is based on $69.73 \%$ of the total respondents. Only $29.5 \%$ of students have a stable internet network while $70.5 \%$ do not have a stable internet network. This problem of internet facilities is even more appreciable when considering the sufficient internet data (with $72.2 \%$ of students with difficulties and, of them, $27.8 \%$ having sufficient internet data for their online learning). Therefore, insufficient internet data is the most significant challenge faced by students. The respondent reported that they sometimes run out of internet data and miss the online classes.

The analysis of students' interviews concurs with that of the quantitative data discussed above. For instance, most of the students during the interview expressed that they do not have online digital banking facilities and could not recharge the data for the online classes.

For instance, Student-2 expressed that;

Getting the internet data was difficult during the lockdown because shops were closed and at the same time we were not allowed to come out to buy the internet data. Moreover, we did not have online digital banking to recharge data.

Similarly, Student-8 revealed that, "Internet data was the big problem while attending an online class. It was difficult submitting my home work and assignments through Google Classroom even if the assignments were completed because of insufficient data."

As noted by the respondents, unstable net work affected their online classes greatly as outlined by Student-13 as, "There was a problem with the network connection." There was a fluctuation in 
the mobile network and it was difficult downloading the materials sent by the teachers through the Google classroom." In a similar manner, Student-18 stated that, "With the fluctuation in the internet, it was very difficult submitting my home work and assignments on time."

The interview analysis revealed that it was difficult for students to attend the online classes due to the lack of internet facilities. Consequently, the problems of internet data and an unstable network impacted the success of online learning during the COVID-19 pandemic. As a result, students could not follow the online lessons effectively and experienced delay in completing and submitting an assignment assigned by teachers.

Table 3

Challenges in Online Learning Due to Lack of Digital Equipments (N=92)

\begin{tabular}{lcc}
\hline Statement & Agree & Disagree \\
\hline 1. Have personal smart phone that support online learning applications. & $60 \%$ & $40 \%$ \\
2. Have television to watch online classes. & $77.2 \%$ & $22.8 \%$ \\
3. Have personal desktop or laptop to learn online. & $17.9 \%$ & $82.1 \%$ \\
\hline
\end{tabular}

As can be understood from the Table 3 , an average of $51.7 \%$ of the total respondents have access to digital equipment like smart phones and desktop or laptops while an average of $48.3 \%$ of the students do not have access to digital equipment for the online classes. This shows that the unavailability of digital equipment like smart mobile phone $(40 \%)$ and desktops or laptops $(82 \%)$ that support online learning is another factor that affects the students' online learning. And only a few of them $(22.8 \%)$ of the students do not have television for the online lesson broadcasted.

Although the majority $(60 \%)$ of the students have access to a smart phone that supports online learning, during the interview the majority of the respondents confirmed that they share their phone with their parents, brother or sisters because they just have one smart phone in their family. For instance, Sudent-12 expressed that, "We have just one phone in our family. The same mobile phone was also used by my brother for the online learning". The above view is echoed by Student-19 as "I did not have a personal phone. I used my mother's cell phone. Three of us including my brother and younger sister were using the same cell phone for the Google classroom. As we had to share the mobile phone, it was difficult to attend the online class on time". Similarly, Student 5 expressed that "We were two of us sharing the cell phone for the online lesson. As we were sharing the mobile phone, it was difficult to submit the assignment and attend the online class on time".

The respondents confirmed that the difficulties in attending the online classes were also due to the lack of access to television. In this sense, Student-17 asserted that, "Without television at home, I missed quite a good number of lessons broadcast on the national television channel". Another respondent, Student-12 expressed that "During lockdown, my participation in the online classes was greatly affected due to the lack of television. It was not possible to visit my friend's house who had access to television".

During the implementation of online learning during the Covid-19 pandemic, the availability of digital equipment is absolutely essential. However, the challenges that students face in online learning is the lack of smart phone, laptop and television. Not all students have access to digital equipments. Therefore, student participation in online learning was not ideal due to the lack of proper digital devices.

\section{Discussions}

The result from this study indicated that the lack of internet facilities is the most significant challenge faced by the students during the online classes. This includes an unstable internet connection, insufficient internet data and lack of fund to buy the internet data. This is in line with the study conducted by Christiawan et al., (2020) and Asio and Bayucca (2021) who pointed out that students' hardship in learning from home during the pandemic is caused due to the lack of funds to buy internet data and unstable internet network. This finding from this study is also in agreement with the study finding of Wijaya et al., (2020) who found online learning not effective when the internet connection is poor. Furthermore, the finding from this study corroborates with a study conducted by Sun and Chen (2016) who found that internet connectivity powers online education. The findings of the study suggest that if the online class has to be a successful one, then students must have sufficient and stable internet connectivity.

Since students can communicate via any digital equipment like laptop and mobile phone 
during online classes, owning digital devices by individual students for the online class is vital. However, the finding from this study revealed that the challenge faced by students with online classes during the COVID-19 pandemic is the lack of digital equipment. Similarly, the study by Kado et al., (2020) in Bhutan has reported that the lack of digital equipment is the challenge faced by students during the online classes. The finding from this study also aligns with the study of Sofi and Laafou (2020). Because of the inadequate resources like computers, the online education is not effective (Paschal \& Mkulu, 2020). The result from this study also revealed that a certain percent of students do not have access to television for the online lessons broadcasted through the national television.

The students' personal-related factors were also found causing learning difficulties during the pandemic. Students did not learn much from online learning as they fail to understand the online materials provided by their teachers due to their insufficient knowledge of internet access for online learning and lack of time to work on the online assignments. In a previous study by Islam et al., (2020) the personal challenge is one of the prioritized challenges for students with the online education. The same personal difficulties were found in previous studies by Christiawan et al., (2020). Thus, the finding from this study indicated that the students prefer face-to-face teaching and learning that involves the classroom socialization. The finding from this study is in agreement with the study finding of Adnan and Anwar (2020) that showed the lack of proper interaction with instructors and absence of classroom socialization as the major challenges associated with online learning. The finding of this study also indicated that student participation in online learning was not ideal due to the lack of proper digital devices and internet facilities. This is found to be challenging for the education system in Bhutan (Pokhrel \& Chhetri, 2021).

\subsection{Conclusions and Recommendations}

The finding from this study revealed that there were many challenges faced by the students in learning online from home during the pandemic. The biggest challenges for students were insufficient internet data to participate in online learning, and lack of digital equipment. Students also found it difficult to comprehend and understand online materials provided by the teachers due to the lack of personal interactions. Also, the student's progress of online learning was hindered by the lack of time and insufficient digital knowledge. As per the finding from this study, it is highly recommended that the ministry of education provides digital equipment and affordable internet for students to overcome the learning difficulties during such a pandemic and continue with the smooth transition to online learning. The findings of this study may not be generalized to the bigger population of Bhutan, as the study was focused on just one middle secondary school based in the Thimphu district, Bhutan.

\subsection{Limitations}

There are number of limitations in this study. The study is limited to students of class nine and ten only. The finding from this study would have been richer if students from other grades were involved. On the other hand, this study did not involve teachers because the intention of the study was to find out the difficulties faced by the students. However, the findings from the study would have been more enriching if teacher participants were also involved. Moreover, only the students from the middle secondary school in the Thimphu district participated in the study. The next research on challenges in online learning should include different students from different schools in the Thimphu District.

Acknowledgement. We would like to thank the principal and parents of the Thimphu District for accepting our proposal to employ the students of classes nine and ten as participants for this study. We would also like to thank all the students who had managed to participate in our data collection process despite their busy schedules.

\section{References}

Adnan, M., \& Anwar, K. (2020). Online learning amid the COVID-19 pandemic: Students' perspectives. Journal of Pedagogical Social and Psychology, 2(1), 45-51. http://www.doi.org/10.33902/JPSP.2020261309 
Asio, J.M.R. \& Bayucca, S.A. (2020). Spearheading education during the COVID-19 rife: Administrators' level of digital competence and schools' readiness on distance learning. Journal of Pedagogical Sociology and Psychology, 3(1), 19-26. https://doi.org/10.33902/JPSP.2021364728

Christiawan, P. I., Astawa, I. B., \& Wesnawa, I. G. (2020). Learn from home in the COVID-19 pandemic: The new difficulties. Advances in Social Science, Education and Humanities Research, 491, 1329-1333.

Creswell, J. W. (2014). Research design. New Delhi: Sage.

Drucker, D. J., \& Fleischhauer, K. (2021). Language pedagogy in a pandemic: The shift to online instruction at a German university during the COVID-19 crisis. Journal of Pedagogical Research, 5(1), 172-187. https://doi.org/10.33902/JPR.2021167474

Drukpa, U. (2020). Students adjust to online learning and its challenges. https://thebhutanese.bt/students-adjust-to-online-learning-and-its-challenges

Ha, Y., \& Im, H. (2020). The role of an interactive visual Learning tool and its personalizability in online learning: Flow experience. Online Learning Journal, 24(1), 205-226. https://doi.org/10.24059/olj.v24i1.1620

Hammond, L. D., \& Hyler, M. E. (2020). Preparing educators for the time of COVID and beyond. European Journal of Teacher Education, 43(4), 457-465. https://doi.org/10.1080/02619768.2020.1816961

Islam, M. R., Rahman, M. M., Kabir, M. Z., Rahman, S., \& Kabir, S. (2020). Assessing the challenges in online class during the coronavirus (COVID-19) pandemic in Bangladesh. Academy of Strategic Management Journal, 19(1), 1-8.

Kado, K., Dem, N., \& Yonten S. (2020). Effectiveness of Google classroom as an online learning management system in the wake of COVID-19 in Bhutan: Students' perceptions. In I. Sahin \& M. Shelley (Eds.), Educational practices during the COVID-19 viral outbreak: International perspectives (pp. 121-142). ISTES Organization. https://orcid.org/0000-0001-7781-8140

Kamal, A. A., Shaipullah, N. M., Truna, L., Sabri, M., \& Junaini, S. N. (2020). Transitioning to online learning during COVID-19 pandemic: Case study of a pre-university centre in Malaysia. International Journal of Advanced Computer Science and Applications, 11(6), 217-223.

Kara, A., \& Gök, A. (2020). Positive and negative affect during a pandemic: Mediating role of emotional regulation strategies. Journal of Pedagogical Research, 4(4), 484-497. https://doi.org/10.33902/JPR.2020064452

Khalil, R., Mansour, A. E., Fadda, W. A., Almisnid, K., Aldamegh, M., Al-Nafeesah, A., ... \& AlWutayd, O. (2020). The sudden transition to synchronized online learning during the COVID19 pandemic in Saudi Arabia: a qualitative study exploring medical students' perspectives. BMC Medical Education, 2O(1), 1-10. https://doi.org/10.1186/s12909-020-02208-z

Kombo, D. K., \& Tromp, D. L. (2006). Proposal and thesis writing: An introduction. Paulines Publication.

Lodico, M. G., Spaulding, D. T., \& Voegtle, K. H. (2006). Methods in educational research. JosseyBass.

Malina, M. A., Norreklit, H. S., \& Selto, F. H. (2011). Lessons learned: Advantages and disadvantages of mixed method research. Qualitative Research in Accounting and Management, 8(1), 59 -71. https://doi.org/10.1108/11766091111124702

Oyedotun, T. D. (2020). Sudden change of pedagogy in education driven by COVID-19: Perspectives and evaluation from a developing country. Research in Globalization, 2, 1-5. https://doi.org/10.1016/j.resglo.2020.100029

Paschal, M. J., \& Mkulu, D. G. (2020). Online classes during COVID-19 pandemic in higher learning institutions in Africa. Global Research in Higher Education, 3(3), 1-21.

Pokhrel, S., \& Chhetri, R. (2021). A literature review on impact of covid-19 pandemic on teaching and learning. Higher Education for the Future, 8(1), 133-141. https://doi.org/10.1177/2347631120983481

Preradović, N. M., Lauc, T., \& Panev, I. P. (2020). Investigating interactivity in instructional video tutorials for an undergraduate informatics course. Issues in Educational Research, 30(1), 203223. http://dx.doi.org/10.22158/grhe.v3n3p1

Rasmitadila., Aliyyah, R. R., Rachmadtullah, R., Samsudin, A., Syaodih, E., Nurtanto, M., \& Tambunan, A. R. S. (2020). The perceptions of primary school teachers of online learning during the covid-19 pandemic period: A case study in Indonesia. Journal of Ethnic and Cultural Studies, 7(2), 90-109. http://dx.doi.org/10.29333/ejecs/388.

Rinzin, Y. C. (2020). Learning should continue e-Learning is optional: PM. Kuensel. 
Shetty, S., Shilpa, C., Dey, D., \& Kavya, S. (2020). Academic crisis during COVID 19: Online classes, a Panacea for imminent doctors. Indian Journal of Otolaryngology and Head \& Neck Surgery, 1-5. https://doi.org/10.1007/s12070-020-02224-x

Sofi, A., \& Laafon, M. (2020). Effect of using the online learning platform in teaching during the COVID-19 pandemic. In I. Sahin \& M. Shelley (Eds.), Educational practices during the COVID-19 viral outbreak: International perspectives (pp. 167-180). ISTES Organization.

Sun, A., \& Chen, X. (2016). Online education and its effective practice: A research review. Journal of Information Technology Education: Research, 15, 157-190.

Sundarasen, S., Chinna, K., Kamaludin, K., Nurunnabi, M., Baloch, G. M., Khoshaim, H. B., ... \& Sukayt, A. (2020). Psychological impact of COVID-19 and lockdown among university students in Malaysia: Implications and policy recommendations. International Journal of Environmental Research and Public Health, 17(17), 6206. https://doi.org/10.3390/ijerph17176206

Thanji, M., \& Vasantha, S. (2018). A Study of benefits and limitations of e-learning-A learner's perspective. International Journal of Pure and Applied Mathematics, 118(5), 175-184.

Tongco, M. (2007). Purposive sampling as a tool for informant selection. Ethnobotany Research \& Applications, 147-158.

Wangmo, U., Nesor, M. R., Choki, S., Om, L., Dorji, K., Dema, N., Sonam, N., Wangchuk, D., \& Tshering, N. (2020). Students' perception on E-Learning in Punakha Dzongkhag in Bhutan. Asian Journal of Education and Social Studies, 11(2), 18-24. https://doi.org/10.9734/ajess/2020/v11i230286

Wijaya, T. T., Zhou, Y., Purnama, A., \& Hermita, N. (2020). Indonesian students' learning attitude towards online learning during the coronavirus pandemic. Psychology, Evaluation, and Technology in Educational Research, 3(1),17-25. https://dx.doi.org/10.33 292/petier.v3i1.56 